\title{
Surgical Reconstruction of the Eyelids after Tumor Excision: Our Experience with 147 Cases
}

\section{Göz Kapağı Tümör Eksizyonu Sonrası Rekonstrüksiyon Tekniklerimiz: 147 Olgu ile Deneyimlerimiz}

\author{
Fadime Nuhoğlu1', Fatma Esin Özdemir², Dilek Abul², Kübra Sarıcı² \\ 'Department of Opticianry, Gelişim University, Health Occupation Vocation School, İstanbul, Turkey \\ 2Department of Ophthalmology, İstanbul Training and Research Hospital, i̇stanbul, Turkey
}

\begin{abstract}
Objective: To evaluate the outcomes of various methods for surgical reconstruction of upper and lower eyelids after tumor excision.

Methods: Data from 147 cases that were operated on due to tumors of the upper or lower eyelids between 2007 and 2011 were retrospectively analyzed. Surgical success was described as defect closure, proper valve function, appropriate lid contour, and good cosmetic appearance. Postoperative follow-up was performed on the 1st day and 1st week and every month afterwards.

Results: The mean duration of follow-up was 8.9 months (6-36 months). Types of surgical interventions consisted of elliptical excision, sutureless excision, rotational flap, advancement flap, Tenzel flap, and blepharoplasty. Scarring at the medial canthus, lid contour deformity, and trichiasis were the complications encountered in the postoperative period. Winking reflex was preserved, and complete closure of eyelids was provided in all of the patients. The overall rate of surgical success was found to be $94.6 \%$.

Conclusion: Reconstruction of eyelids is an important issue after the complete excision of a tumor and achievement of tumor-free margins. The reconstructive technique must be appropriate for the location and the size of the lesion, aiming to provide a proper shape and contour for the eyelids. (JAREM 2014; 4: 97-101)
\end{abstract}

Key Words: Flap, graft, eyelid, tumor, surgery, reconstruction

\section{ÖZET}

Amaç: Alt ve üst göz kapağın malign tümöral kitlelerinin ekzisyonu uygulandıktan sonra oluşan göz kapağı defektlerinde uygulanan rekonstrüksiyon teknikleri ve klinik sonuçlarını değerlendirmek amaçlandı.

Yöntemler: 2007 ve 2011 yılları arasında üst veya alt göz kapaklarında tümöral kitle nedeniyle eksizyon yapılan 147 olgunun verileri retrospektif olarak analiz edildi. Cerrahi başarı defektlerin tamamen kapanması, düzgün kapak fonksiyonu, uygun kapak kontur ve iyi kozmetik görünüm sağlanması olarak değerlendirildi. Ameliyat sonrası takip 1. gün, 1. hafta ve sonrasında aylık olarak yapıldı.

Bulgular: Takip süresi ortalama 8,9 ay (6-36 ay) idi. Kullanılan cerrahi rekonstruksiyon teknikleri eliptik eksizyon, sütürsüz eksizyon, rotasyonel flep, ilerletme flebi, Tenzel flep ve blefaroplasti idi. Medial kantusta yara izi, kapak kontur deformitesi ve trikiyazis postoperatif dönemde karşılaşılan komplikasyonlardı. Göz kırpma refleksi tüm olgularda korundu. Göz kapaklarının tam kapanması bütün olgularda sağlandı. Cerrahi başarı oranı \% 94,6 idi.

Sonuç: Göz kapaklarını tümöral kitlelerinin tam eksizyonu sonrası düzgün kapak kontur ve pozisyonunun sağlanması önemlidir. Rekonstrüksiyon teknikleri göz kapakları için uygun bir şekil ve kontur sağlamayı amaçlamalı, lezyonun yerleşimine ve büyüklüğüne uygun olmalıdır. (JAREM 2014; 4: 97-101)

Anahtar Sözcükler: Cerrahi, flep, greft, göz kapağı, rekonstrüksiyon, tümör

\section{INTRODUCTION}

The eyelids are important for the protection of the globe and maintenance of corneal hydration. Minor eyelid dysfunction can cause disturbances in visual acuity, even leading to blindness due to corneal desiccation. The eyelids glide over the globe and aid in cleansing and lubrication via spreading tears across the cornea. They not only provide flexibility during the opening and closure of the eyes and maintain elasticity but also maintain the canaliculi opposed to the lacrimal lake. The eyelids are important components of physical beauty. Hence, proper reconstruction of the eyelids is an important challenge after tumor surgery (1-3).
A variety of techniques may be necessary for safe and reliable outcomes in the reconstruction of eyelids after excision of a tumor. For a simple defect, a typical procedure may be sufficient; however, with more complex defects, the standard procedure may fall short. The best approach to complex defects is adequate analysis, and the use of different reconstructive techniques is critical. Defect analysis is the first stage of eyelid reconstruction to determine the missing anatomical parts. The patient's requirements must also be taken into account during the formulation of surgical modality. The close proximity of the lacrimal system to the medial canthal region must be remembered for proper diagnosis and treatment (1-3). 
In this study, we present our clinical outcomes of upper and lower eyelid reconstruction after tumor excision.

\section{METHODS}

The study was approved by the appropriate ethics authority. Written informed consent was obtained from all subjects or a legal surrogate, or the requirement for written informed consent was waived by the ethics committee. A retrospective analysis was performed for 147 eyes of 123 patients who were operated on due to tumor of the upper or lower eyelids. Twenty-three patients had been operated on in both eyes. The study was approved by the institutional review board, and data were obtained from the medical records. All patients had been treated in the ophthalmology department of a tertiary care center. A complete ophthalmological examination was conducted on all patients.

For presumably benign lesions, those $\leq 4 \mathrm{~mm}$ were closed with strips without suturing. Defects formed after excision of lesions $>4 \mathrm{~mm}$ were repaired with primary closure, grafts, or flaps.

For lesions that were likely to be malignant, excisional biopsy with 3-mm tumor-free margins was performed, and frozen biopsies were simultaneously performed. In cases in which frozenbiopsy revealed positivity for a tumor, re-excision was performed.

Local anesthesia was accomplished by infiltration with lidocaine $\mathrm{HCl}(20 \mathrm{mg} / \mathrm{mL})$ and epinephrine $\mathrm{HCl}(0.0125 \mathrm{mg} / \mathrm{mL})$. Skin grafts were harvested from retroauricular skin or the area of dermatochalasis, whereas cartilage grafts were obtained from the auricle. Topical sponges gauzed with antibiotics were placed over the graft for the first 48 hours. Normally, sutures were removed at 7-10 days postoperatively, while stitches on the free margin of eyelids were removed on 14-21 days. Follow-ups were performed on the $1^{\text {st }}$ day, $1^{\text {st }}$ week, and $1^{\text {st }}$ month and monthly afterwards. The mean duration of follow-up was 8.9 months (6-36 months).

Surgery was described as successful with respect to closure of the defect, maintenance of eyelid function, proper eyelid contour, and good cosmetic result.

\section{Statistical Analysis}

Data were analyzed using the Statistical Package for Social Sciences (SPSS) software (version 10.0 for Windows). All differences associated with a chance probability of .05 or less were considered statistically significant. Chi-square and Mann-Whitney $\mathrm{U}$ tests were performed on nominal data.

\section{RESULTS}

The average age was $47.7 \pm 19.7$ (3-79) for 124 patients (74 females, 49 males). Simple excision, elliptical excision, rotational flap, advancement flap, full-thickness free margin repair, Tenzel semicircular flap, skin graft, and O-Z plasty were the types of operations performed in our series (Figures 1-6). The types of surgery and number of patients that had undergone the particular intervention are demonstrated on Tables 1. Canaliculostomy and silicone stenting were performed on 4 cases, while blepharoplasty was conducted on 7 of 23 (30.4\%) xanthelasma patients. In terms of postoperative complications, retraction due to scarring of the medial canthus, deformity on the eyelid contour, and trichiasis were encountered in 5, 2, and 1 cases, respectively.
Table 1. Types and numbers of surgical interventions performed

\begin{tabular}{|l|c|}
\hline Surgical method & no (\%) \\
\hline Elliptical excision & $44(29.9 \%)$ \\
\hline Sutureless excision & $25(17 \%)$ \\
\hline Rotational flap & $23(15.6 \%)$ \\
\hline Advancement flap & $22(14.9 \%)$ \\
\hline Tenzel semicircular flap & $10(6.8 \%)$ \\
\hline Blepharoplasty & $7(4.7 \%)$ \\
\hline
\end{tabular}

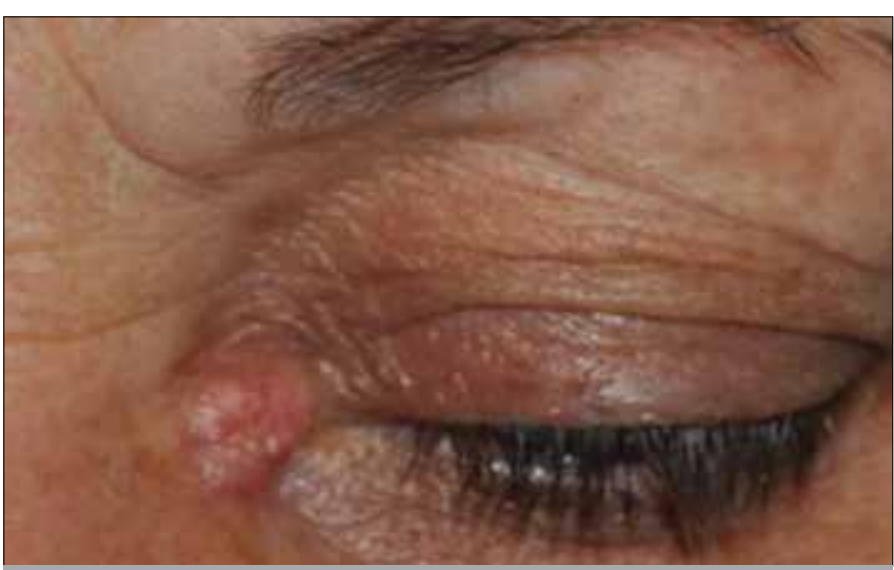

Figure 1. A case of nodular basal cell carcinoma located on medial canthi

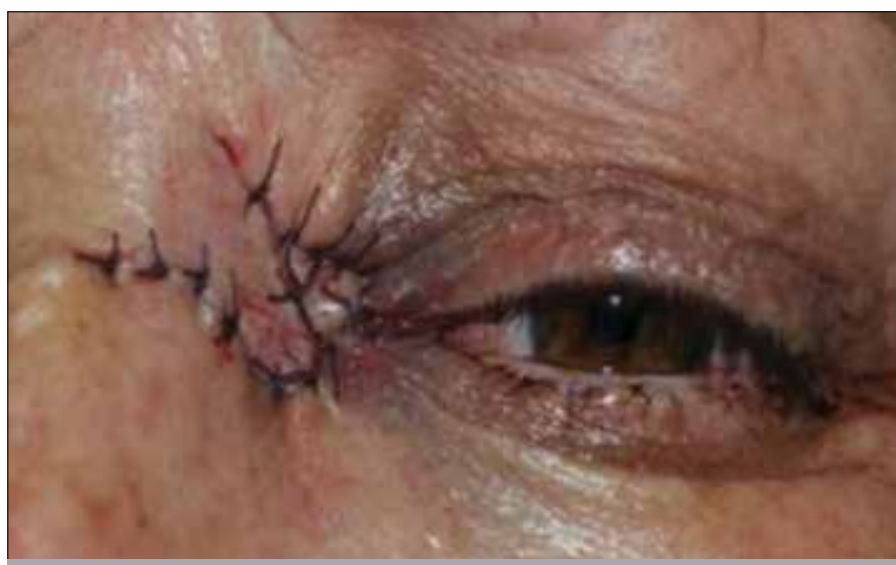

Figure 2. View after rhomboid-shaped excision and reconstruction with nasal advancement flap

In all of the patients, winking reflex and complete eye closure were preserved. The overall rate of surgical success was found to be $94.6 \%$.

\section{DISCUSSION}

Reconstruction of the eyelids is a complex procedure, since the tissue is quite elastic, thin, and pliable. Eyelids are dynamic structures located in the most noticeable area of the body that protect the most coveted cranial nerves. In addition to tumor excision and complete eradication of neoplasm, reconstructive procedures call for substantial anatomic and surgical knowledge, detailed analysis, and careful planning. Each procedure should 


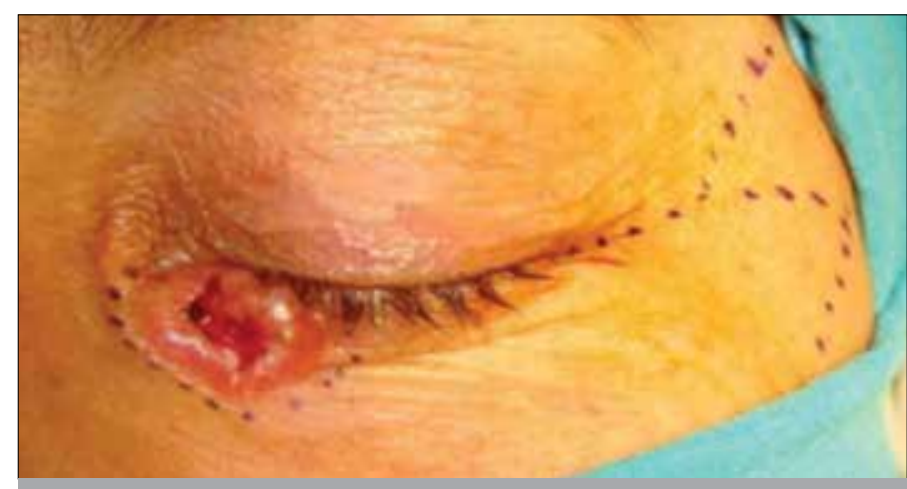

Figure 3. Preoperative view of an ulceronodular-type basal cell carcinoma at the medial canthi

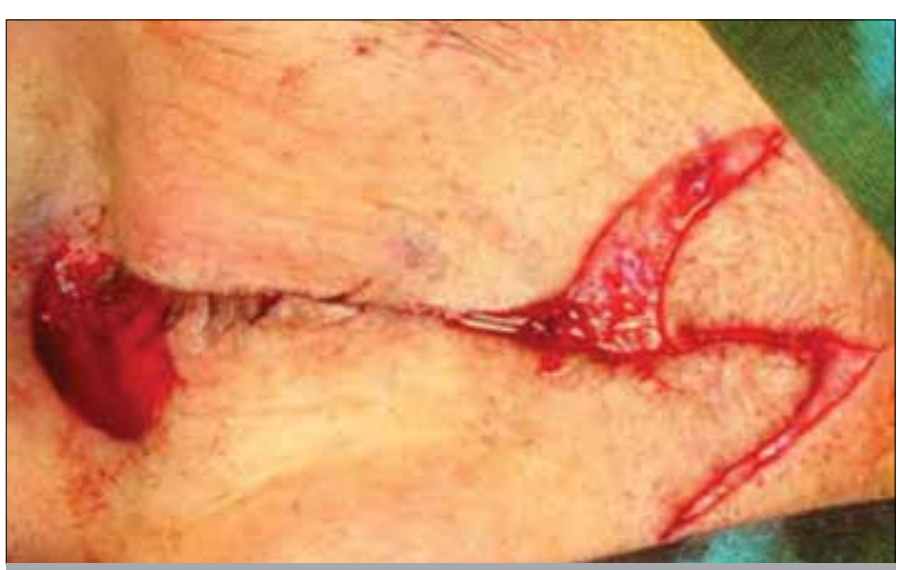

Figure 4. Z-plasty after complete excision of tumor with safe margins

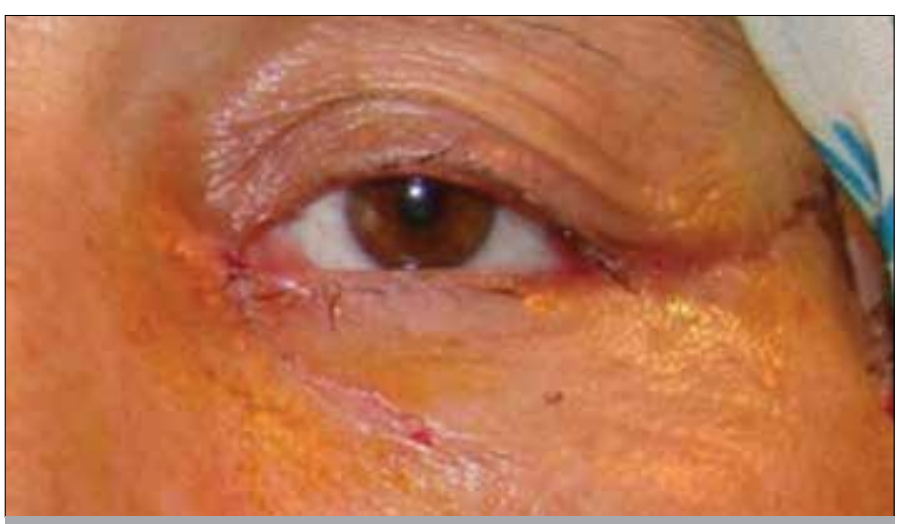

Figure 5. Postoperative day 14 view of the case in Figures 3 and 4

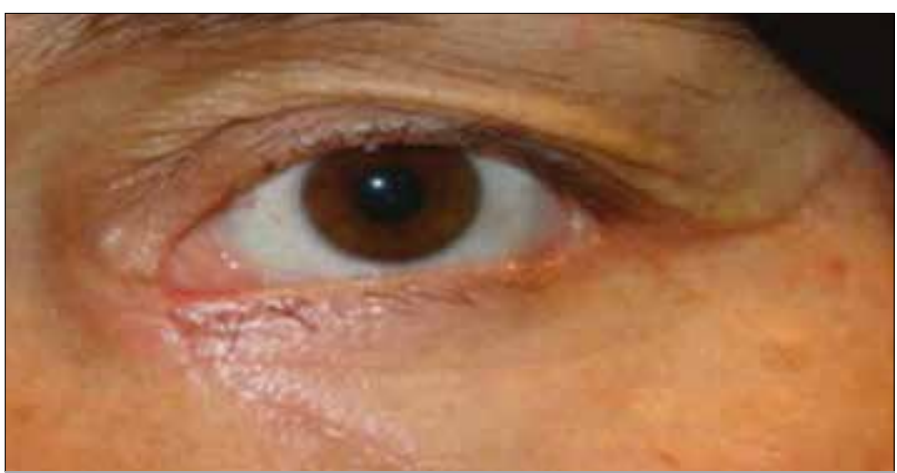

Figure 6. Postoperative month 1 view of the case in Figures 3 and 4 be preceded by an investigation of preoperative eyelid function and position. The optimal method of reconstruction must be selected according to the extent and location of the defect and the patient's wishes. The procedure must preserve the structural support, as well (1-3).

The methods used for reconstruction of upper or lower eyelids share a similar philosophy. Proper reconstruction of the upper lid is important, since it protects the majority of the cornea and the remainder of the eye. The lining and margin of the upper lid must be precisely repaired, since it makes contact directly with the cornea with each blink. A rough surface from scarring of the eyelid margin or lining of the upper lid can injure the cornea and cause patient discomfort. Lower eyelid reconstruction can be performed with direct closure or lateral-based rotation flaps and vertical myocutaneous flap. Full-thickness skin grafts can be used for adequate reconstruction of small superficial defects (1-3).

In severe cases with full-thickness loss of both the upper and lower eyelids, protection of the cornea from exposure and ulceration is the main goal. Since these cases are often associated with trauma, local tissue may be unavailable for reconstruction. Corneal protection can be provided by advancing residual conjunctiva or tarsoconjunctiva from the upper and lower fornix over the cornea. The conjunctival flaps completely cover the cornea, and a musculocutaneous flap or full-thickness skin graft is used to cover and protect the globe. An ear cartilage graft can function as an interposition graft between the flap and the conjunctiva (1-3).

In elderly patients, even larger defects may be repaired with primary suturing, since the skin is more elastic and loose. In contrast, reconstruction in patients with a history of radiotherapy or previous surgery may constitute a challenge. In defects occupying up to $25 \%$ of the eyelid area, primary suturing is commonly used. This method may work for defects constituting even half of the surface area in elderly patients. In order to avoid notching and folding on the lid margins, excision lines must lie in parallel and should cover the whole vertical length of the tarsal plate. In middle-sized tumors involving 25\%-50\% of the eyelid area, a primary closure may not be always possible, and canthotomy or cantholysis may be required (4).

Defects formed after the excision of lesions around the lateral canthus may be transformed into a rhomboid shape for the facilitation of closure. Lower eyelid defects around the lateral canthus can be reconstructed using lateral-based tarsoconjunctival flaps, skin grafts, and periosteal flaps (5).

Knowledge and experience on lacrimal system anatomy are necessary for reconstruction after excision of medial canthal lesions. Skin grafts, local transposition flaps, or advancement flaps may be utilized according to the size of the defect. Lesions with deeper extension may call for glabellar or forehead flaps, because secondary healing with granulation or skin grafts is usually not sufficient in this purpose (5).

A suspicion of malignancy brings about the need for a preoperative biopsy. This is crucial for both medico-legal issues and selection of the appropriate intervention that eradicates the neoplasm thoroughly. We observed that the Tenzel flap is a practical measure for defects occupying about two-thirds of the lower eyelid. 


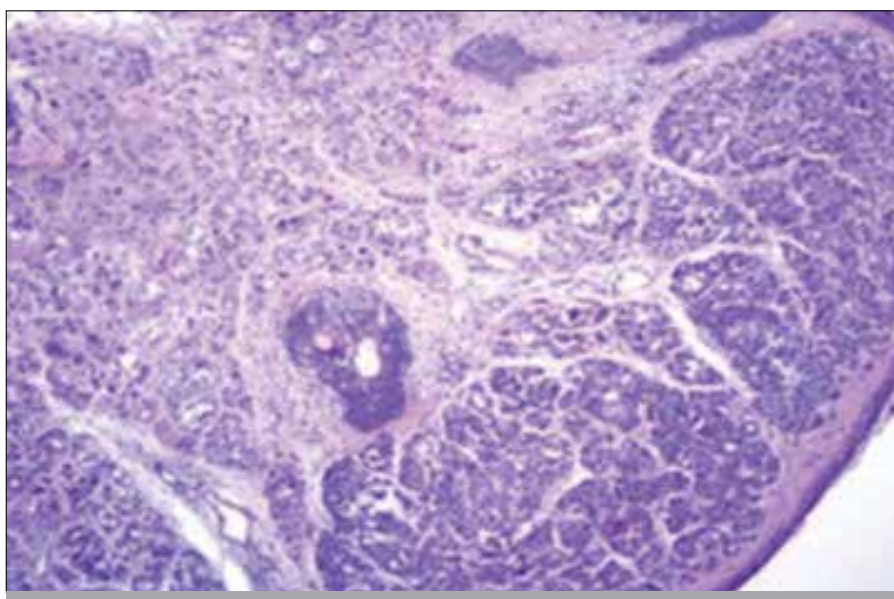

Figure 7. Microscopic view of a nevus. H\&E staining; bar = $100 \mu \mathrm{m} .259$

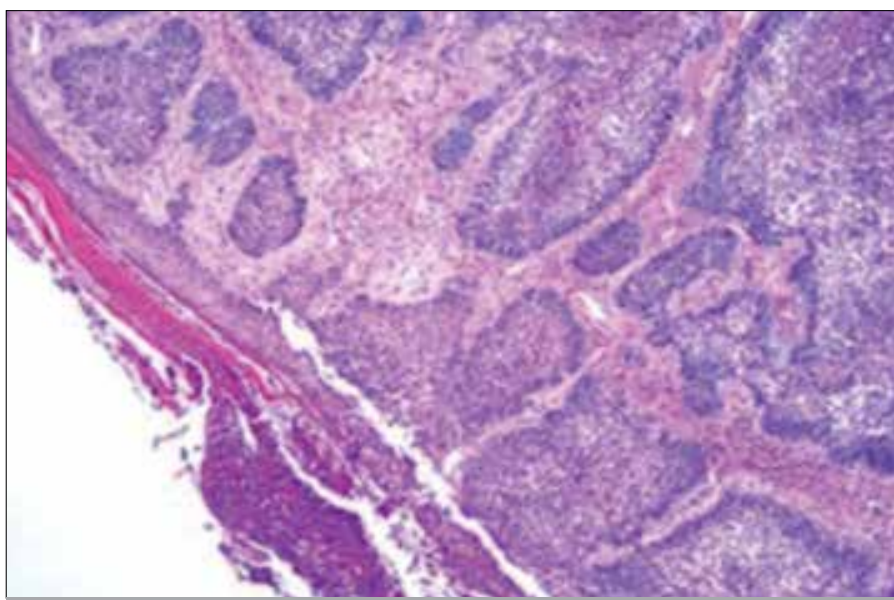

Figure 8. Microscopic view of basal cell carcinoma; H\&E staining; bar = $100 \mu \mathrm{m} .260$

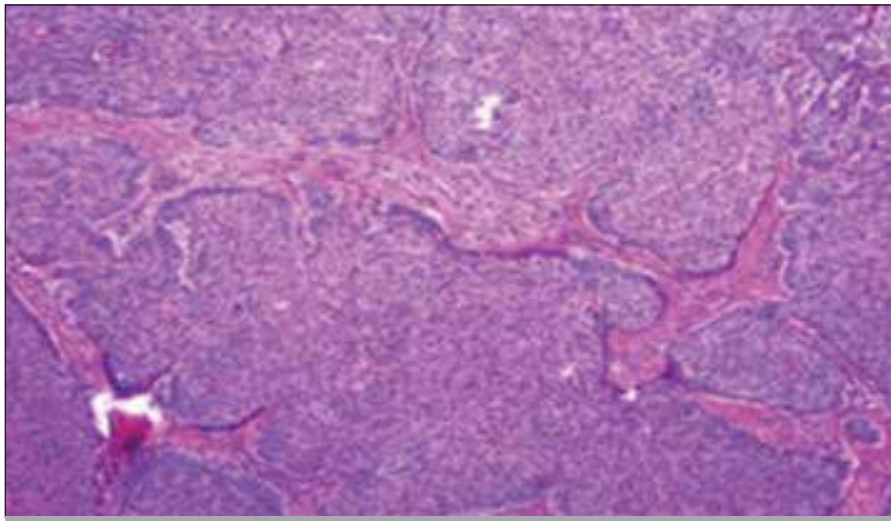

Figure 9. Microscopic view of trichoblastoma; H\&E staining; bar $=100 \mu \mathrm{m}$

Full-thickness pedicled flaps can provide satisfactory cosmetic and functional outcomes for upper eyelid defects corresponding to the cornea.

Defects involving the whole eyelid are challenging. Tarsal graft and double pedicled flaps can be used for reconstruction after total excision of the upper eyelid (6). Repair of the lower eyelid initially starts with fixation of medial and lateral canthi. Canalicular intubation can be performed simultaneously (7). For reconstruction of the medial canthi and upper eyelid, tunneled forehead flaps are practical (8). Myofascial, galeal, and pericranial flaps are alternatives for deeper defects of the same region (9-11).

\section{CONCLUSION}

In conclusion, proper planning for upper and lower eyelid reconstruction begins with fundamental knowledge of eyelid anatomy. Careful analysis of the defect helps create an organized operative plan. Familiarization with the principles and continuously evolving techniques for eyelid reconstruction will provide a number of practical options for the surgeon who is challenged with these reconstructive cases. The operative technique can be specifically tailored on an individualized basis according to the unique features of each patient.

Ethics Committee Approval: Ethics committee approval was received for this study from the ethics committee of İstanbul Training and Research Hospital (03.2010) .

Informed Consent: Informed consent was obtained from patients who participated in this study.

Peer-review: Externally peer-reviewed.

Author Contributions: Concept - F.N.; Design - D.A.; Supervision - F.N.; Funding - F.E.Ö., D.A.; Materials - K.S.; Data Collection and/or Processing - F.E.Ö., D.A.; Analysis and/or Interpretation - F.N.; Literature Review - D.A.; Writing - D.A., F.N., F.E.Ö.; Critical Review - F.N.

Conflict of Interest: No conflict of interest was declared by the authors.

Financial Disclosure: The authors declared that this study has received no financial support.

Etik Komite Onayı: Bu çalışma için etik komite onayı İstanbul Eğitim ve Araştırma Hastanesi Etik Kurulu'ndan alınmıştır (03.2010).

Hasta Onamı: Yazılı hasta onamı bu çalışmaya katılan hastalardan alınmıştır.

Hakem değerlendirmesi: Dış bağımsız.

Yazar Katkıları: Fikir - F.N.; Tasarım - D.A.; Denetleme - F.N.; Kaynaklar F.E.Ö., D.A.; Malzemeler - K.S.; Veri Toplanması ve/veya İşlemesi - F.E.Ö., D.A.; Analiz ve/veya Yorum - F.N.; Literatür Taraması - D.A.; Yazıyı Yazan - D.A., F.N., F.E.Ö.; Eleştirel İnceleme - F.N.

Çıkar Çatışması: Yazarlar çıkar çatışması bildirmemişlerdir.

Finansal Destek: Yazarlar bu çalışma için finansal destek almadıklarını beyan etmişlerdir.

\section{REFERENCES}

1. Codner MA, McCord CD, Mejia JD, Lalonde D. Upper and lower eyelid reconstruction. Plast Reconstr Surg 2010; 126: 231-45. [CrossRef]

2. O'Donnell BA, Mannor GE. Oculoplastic surgery for upper eyelid reconstruction after cutaneous carcinoma. Int Ophthalmol Clin 2009; 49: 157-72. [CrossRef]

3. Suryadevara AC, Moe KS. Reconstruction of eyelid defects. Facial Plast Surg Clin North Am 2009; 17: 419-28. [CrossRef]

4. McCord CD Jr, Codner MA. Malignant eyelid tumors. In: Eyelid and periorbital surgery. (McCord CD Jr, Codner MA, eds.), 1st ed. St. Louis 2008; 461-91.

5. Tyers AG, Collin JRO. Use of skin grafts to fill the defect. In: Colour atlas of ophtalmic plastic surgery (Tyers AG, Collin JRO, eds.), 3rd ed. Philadelphia 2008; 38-48. 
6. Patrinely JR, O'Neal KD, Kersten RC, Soparkar CNS. Total upper eyelid reconstruction with mucosalized tarsal graft and overlying bipedicle flap. Arch Ophthalmol 1999; 117: 1655-61. [CrossRef]

7. McCord CD Jr, Codner MA. Medial and lateral canthal reconstruction: Reconstructive surgery. In: Eyelid and periorbital surgery. (McCord CD Jr, Codner MA, eds.), 1st ed. St.Louis 2008; 503-5.

8. Mombaerts I, Gillis A. The tunneled flap in medial canthal and eyelid reconstruction. Dermatol Surg 2010; 36: 1118-25. [CrossRef]
9. Chiarelli A, Forcignanò R, Boatto D. Reconstruction of the inner canthus region with a forehead muscle flap: a report on three cases. Br J Plast Surg 2001; 54: 248-52. [CrossRef]

10. Guzel MZ. The turnover subdermal-periosteal median forehead flap. Plast Reconstr Surg 2003; 111: 347-50. [CrossRef]

11. Tse DT, Goodwin WJ, Johnson T. Use of galeal or pericranial flaps for reconstruction or orbital and eyelid defects. Arch Ophthalmol 1997; 115: 932-7. [CrossRef] 